\title{
STABILITAS PERFORMA DAN RELIABILITAS IPAL DOMESTIK DENGAN KOMBINASI AERASI SECARA INTERMITTENT DENGAN RESIRKULASI EFLUEN DAN MICROBUBBLE GENERATOR
}

\author{
Johan Syafri Mahathir AHMAD ${ }^{1 *}$, Hafasatya Maharani PUTRI ${ }^{2}$, Nurul Ainun SANTONI ${ }^{1}$, Sri \\ Puji SARASWATI ${ }^{3}$ \\ ${ }^{1}$ Departemen Teknik Sipil dan Lingkungan, Fakultas Teknik, Universitas Gadjah Mada, Yogyakarta, \\ Indonesia \\ ${ }^{2}$ Magister Teknik Sistem, Fakultas Teknik, Universitas Gadjah Mada, Yogyakarta, Indonesia \\ *Email korespondensi: johan.syafri.ma@ugm.ac.id
}

[diterima: 26 Mei 2021, disetujui: 9 Juni 2021]

\begin{abstract}
Recently, various technology has been applied to the domestic wastewater treatment plant (WWTP); however, the reliability, compliance to standards and performance are not well understood. This study discusses the reliability of WWTP in Bulaksumur Residence in terms of compliance to effluent quality standards (for direct discharge) and class IV water quality standards (for irrigation water potential use). The WWTP operates continuously, and its performance was observed for 82 days. This WWTP uses an intermittent aeration system by utilizing wastewater recirculation coupled with a microbubble generator (MBG) nozzle. From the observations, the WWTP shows good and stable performance indicated by its TSS, COD, $\mathrm{PO}_{4}-\mathrm{P}$ removal efficiency of $68,9 \pm 12,9 \%, 78,4 \pm 9,8 \%, 45,3 \pm 8,6 \%$ and $63,4 \pm 13,7 \%$, respectively, as well as its nitritation, nitration and denitrification efficiency $(83,1 \pm 7,9 \%, 97,6 \pm 2,0 \%$ and $67,2 \pm 19,3 \%$, respectively). Effluent quality of TSS $(4,6 \pm 3,4 \mathrm{mg} / \mathrm{l})$, COD $(13,9 \pm 6,6 \mathrm{mg} / \mathrm{l})$, and $\mathrm{NH}_{3}-\mathrm{N}$ $(2,4 \pm 2,4 \mathrm{mg} / \mathrm{l})$ shows $100 \%$ compliance to both regulation standards for effluent discharge and class IV water quality. Likewise for $\mathrm{NO}_{3}-\mathrm{N}(2,8 \pm 0,5 \mathrm{mg} / \mathrm{l})$ also show $100 \%$ compliance to both standards. As for $\mathrm{NH}_{3}-\mathrm{N}(2,4 \pm 2,4 \mathrm{mg} / \mathrm{l})$ and $\mathrm{NO}_{2}-\mathrm{N}(0,22 \pm 0,99)$ only showed similar poor reliability of $8.3 \%$ compliance to class IV water quality standards. The results of this research are expected to contribute to the development and improvement of MBG technology and the optimum aeration strategy to produce WWTP with stable performance and good reliability.
\end{abstract}

Keywords: WWTP reliability and stability, intermittent aeration, microbubble, recirculation.

\section{INTISARI}

Berbagai macam teknologi telah diterapkan pada Instalasi Pengolahan Air Limbah (IPAL) domestik, namun tidak diketahui secara pasti realibitas dan kinerjanya. Penelitian ini membahas tentang realibilitas IPAL di Bulaksumur Residence untuk pemenuhan standar kualitas efluen jika efluen akan dibuang langsung ke lingkungan dan standar kualitas air kelas IV jika efluen IPAL akan digunakan sebagai air penyiraman taman. IPAL beroperasi secara kontinyu dan kinerja IPAL diamati selama 82 hari. IPAL menggunakan sistem aerasi intermittent dengan memanfaatkan resirkulasi air limbah dengan pemasangan microbubble generator (MBG) menunjukkan performa yang baik dan stabil. Efisiensi removal TSS, $\mathrm{COD}, \mathrm{PO}_{4}-\mathrm{P}$ dan $\mathrm{TN}$ berturut-turut sebesar $68,9 \pm 12,9 \%, 78,4 \pm 9,8 \%, 45,3 \pm 8,6 \%$ dan $63,4 \pm 13,7 \%$. Performa yang sangat baik juga terlihat pada efisiensi nitritasi, nitratasi dan denitrifikasi berturut-turut sebesar $83,1 \pm 7,9 \%, 97,6 \pm 2,0 \%$ dan $67,2 \pm 19,3 \%$. Kualitas efluen untuk parameter TSS $(4,6 \pm 3,4 \mathrm{mg} / \mathrm{l})$, $\operatorname{COD}(13,9 \pm 6,6 \mathrm{mg} / \mathrm{l})$ dan $\mathrm{NH}_{3}-\mathrm{N}(2,4 \pm 2,4 \mathrm{mg} / \mathrm{l})$ menunjukkan reliabilitas $100 \%$ baik untuk memenuhi standar kualitas air efluen maupun air kelas IV. Begitu pula untuk $\mathrm{NO}_{3}-\mathrm{N}(2,8 \pm 0,5 \mathrm{mg} / \mathrm{l})$ juga menunjukkan reliabilitas $100 \%$ untuk memenuhi standar kualitas air kelas IV. Sedangkan untuk $\mathrm{NH}_{3}-\mathrm{N}$ $(2,4 \pm 2,4 \mathrm{mg} / \mathrm{l})$ dan $\mathrm{NO}_{2}-\mathrm{N}(0,22 \pm 0,99)$ hanya menunjukkan reliabilitas sebesar masing-masing $8,3 \%$. Hasil dari penelitian ini diharapkan dapat memberikan kontribusi terhadap perkembangan teknologi dan strategi operasional IPAL terutama dengan teknologi MBG untuk menghasilkan kinerja yang stabil dan memiliki reliabilitas yang tinggi. 
Kata kunci: Reliabilitas dan stabilitas IPAL, aerasi intermittent, microbubble, resirkulasi.

\section{PENDAHULUAN}

Air limbah domestik yang dibuang langsung tanpa diolah baik diresapkan ke tanah maupun ke badan air dapat berakibat buruk bagi lingkungan. Kandungan bakteri E.coli yang tinggi di air tanah merupakan salah satu indikasi bahwa air tanah sudah tercemar oleh air limbah domestik (Rompas et al., 2019). Menurunnya indeks kualitas air di Sungai Gadjah Wong, Yogyakarta (Putro, 2017; Saraswati et al., 2019) juga dapat menjadi indikasi terjadinya pencemaran yang salah satu penyebab utamanya adalah pembuangan air limbah domestik tanpa diolah. Meskipun tidak menunjukkan relevansi secara langsung terhadap kondisi biotik di badan air, kadar COD dapat merepresentasikan tingginya pencemar organik di badan air (Niemi et al., 2006), sedangkan kadar nutrien yang tinggi di badan air dapat meningkatkan pertumbuhan fitoplankton yang dapat menyebabkan terjadinya algae bloom di perairan (Mahlil et al., 2018; Matthews, 2008)

Dalam rangka pengendalian pencemaran air, Kementerian Lingkungan Hidup dan Kehutanan (LHK) mengesahkan Peraturan Menteri LHK No. 68 tahun 2016 tentang baku mutu air limbah yang mengatur batasan maksimal konsentrasi pencemar yang diijinkan untuk dibuang ke lingkungan. Untuk memenuhi standar kualitas air limbah yang telah ditetapkan, berbagai metode, strategi, dan konfigurasi Instalasi Pengolahan Air Limbah (IPAL) baik secara individu, komunal maupun terpusat telah diterapkan. Diantara dua proses utama dalam IPAL, aerobik dan anaerobik, proses anaerobik lebih disukai untuk diterapkan pada IPAL komunal. Hal ini dapat dikarenakan konsumsi energi pada proses anaerobik lebih rendah dibandingkan dengan proses aerobik dimana pada proses aerobik membutuhkan energi untuk aerasi. Sedangkan pada IPAL terpusat di Sewon, Bantul menggunakan proses aerasi pada kolam fakultatif. Dari studi terdahulu yang sudah dilakukan (Ahmad et al., 2017, 2019), penghematan energi di IPAL dapat dilakukan salah satunya dengan strategi intermittent aeration dibandingkan dengan aerasi secara menerus (24 jam) dikarenakan pada intermittent aeration terdapat periode dimana aerasi tidak dilakukan sehingga penggunaan total energi dapat lebih rendah.

Hingga saat ini, belum dapat diketahui secara pasti kinerja, stabilitas dan reliabilitas dari berbagai macam IPAL yang ada. Hal ini dikarenakan pemantauan kualitas air secara rutin belum dapat terlaksana dengan baik, terutama pada IPAL skala kecil hingga menengah. Berbeda dengan IPAL skala besar atau IPAL untuk kegiatan komersial, seperti hotel dan pusat perbelanjaan, yang dikenakan kewajiban untuk melakukan pengujian kualitas air efluen dan melaporkan secara berkala kepada Badan/Dinas Lingkungan Hidup setempat.

Pemanfaatan microbubble generator (MBG) nozzle sebagai alat aerasi pada IPAL merupakan terobosan baru pada perkembangan teknologi aerasi. MBG nozzle pada umumnya dipasang pada discharge pompa. Hal tersebut merupakan keunggulan yang mengakibatkan MBG memiliki dua fungsi yang dapat bekerja bersamaan yaitu sebagai resirkulasi air limbah dan sekaligus dapat mensuplai oksigen untuk kebutuhan aerasi. Dari studi sebelumnya, diketahui bahwa koefisien transfer massa oksigen dengan MBG lebih tinggi dari aerator tipe lain karena ukuran gelembung udara yang dihasilkan lebih kecil (skala mikron) (Shalindry et al., 2015).

Bulaksumur Residence adalah asrama mahasiswa Universitas Gadjah Mada yang menggunakan IPAL dengan kombinasi antara strategi aerasi dan secara spesifik menggunakan intermittent aeration dan MBG dengan resirkulasi air limbah. IPAL tersebut 
secara spesifik menggunakan MBG untuk aerasi dan tidak ada jenis aerator lain yang terpasang di dalamnya selama operasional. Sejauh penelusuran pustaka yang telah dilakukan oleh penulis, belum ditemukan informasi tentang kinerja, stabilitas dan reliabilitas IPAL dengan sistem aerasi menggunakan MBG dan strategi intermittent aeration. Hasil dari penelitian ini diharapkan dapat memberikan kontribusi bagi pengembangan dan penyempurnaan teknologi MBG dan strategi aerasi yang tepat untuk menghasilkan IPAL dengan kinerja yang stabil dan reliabilitas yang baik.

\section{METODE PENELITIAN}

\section{Konfigurasi IPAL}

Lokasi IPAL terletak di Asrama Mahasiswa Ratnaningsih Bulaksumur Residence yang melayani 42 kamar dengan penghuni 2 orang per kamar. IPAL hanya mengolah greywater dari kamar mandi, dan wastafel setiap kamar dan wastafel dapur umum yang berjumlah satu dapur di setiap lantai. Asrama Ratnaningsih Bulaksumur Residence memiliki 4 lantai.

Skema pengolahan air limbah pada IPAL tersaji pada Gambar 1. Air limbah yang dihasilkan dari gedung asrama dialirkan ke sebuah tangki ekualisasi (1.050 1) berjenis tangki timbun. Sebuah pompa celup dengan kapasitas maksimal 115 1/menit (Multipro SP125-DWMP, 125W, Indonesia) yang dilengkapi dengan auto level switch, yang dapat menyalakan dan mematikan pompa sesuai beradasarkan level air di dalam tangki ekualisasi, digunakan untuk mengalirkan air limbah ke tangki aerasi 1 . Sebuah water meter dipasang pada inlet tangki aerasi 1 untuk mencatat volume air limbah yang masuk ke sistem pengolahan.

Dari tangki aerasi 1 air limbah mengalir secara gravitasi ke tangki aerasi 2 dan tangki pengendap akhir (volume masing-masing 1.050 1). Dari bak pengendap akhir, air limbah terolah di resirkulasi ke tangki aerasi 1 dan 2 dengan masing-masing pompa sentrifugal dengan debit 21.7 1/menit (Shimizu PS-121 BIT, 125W). Microbubble generator (MBG) nozzle dipasang pada inlet pipa resirkulasi ke masing-masing tangki aerasi 1 dan 2 dengan tujuan pada saat resirkulasi berlangsung, udara akan masuk pada MBG nozzle dan ikut masuk bersama air resirkulasi ke tangki aerasi sehingga blower tidak lagi diperlukan untuk mensuplai udara pada proses aerasi. Proses resirkulasi (bersamaan dengan aerasi) dilakukan secara intermittent (15 menit menyala - 15 menit mati) diatur dengan auto timer switch. Selain untuk menghemat penggunaan energi, aerasi secara intermittent dilakukan untuk mengakomodasi proses nitrifikasi dan denitrifikasi pada satu tangki yang sama.

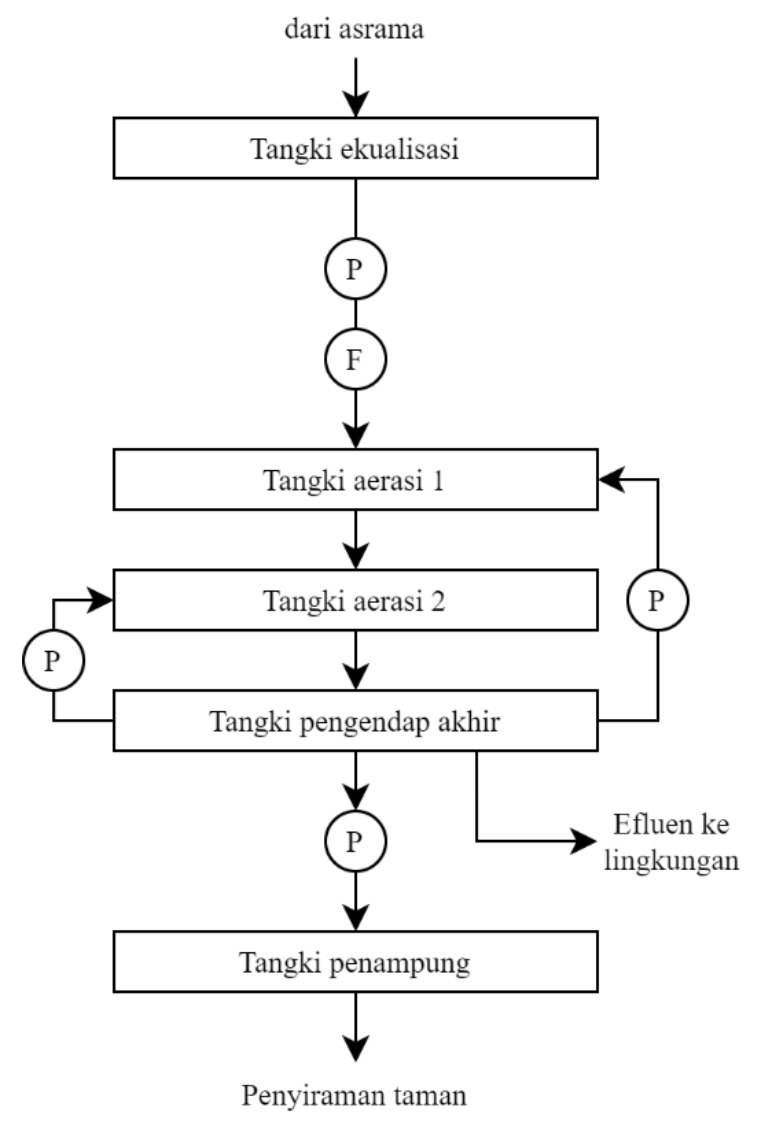

Gambar 1. Skema proses pada IPAL: simbol P adalah pompa dan $\mathrm{F}$ adalah flowmeter

Terdapat dua outlet pada tangki pengendap akhir; pertama, outlet menuju ke tangki penampungan air olahan yang terdapat 
pada lantai 4 gedung asrama dialirkan dengan pompa semi-jet dengan kapasitas 44 1/menit (Shimizu JET-100 BIT, 100W, Indonesia). Dari tangki penampung tersebut, air olahan akan digunakan untuk penyiraman kawasan Asrama; kedua, outlet menuju selokan. Jika air pada tangki penampung penuh, maka efluen IPAL akan dibuang ke selokan. Seluruh tangki pada IPAL menggunakan tangki high density polyethylene (HDPE) dan power meter untuk mengukur penggunaan energi listrik dipasang pada setiap pompa.

\section{Pengambilan Sampel dan Uji Kualitas Air}

Pengukuran debit dan pengambilan sampel untuk uji kualitas air dilakukan sebanyak dua kali dalam seminggu pada hari selasa dan minggu (pada waktu yang sama), untuk merepresentasikan kondisi normal dan kondisi puncak penggunaan air, dari 4 Oktober 2020 hingga 24 Desember 2020. Pengukuran debit dilakukan dengan menghitung selisih volume air pada water meter dibagi dengan durasi pengamatan. Pengambilan sampel air limbah dilakukan pada influen dan efluen IPAL. Influen IPAL yang diambil adalah inlet tangki aerasi 1 dan efluen IPAL adalah outlet tangki bak pengendap akhir. Pada saat pengambilan sampel air juga dilakukan pengukuran konsentrasi oksigen terlarut (DO) pada saat aerasi terjadi (pompa resirkulasi menyala) dan tanpa aerasi (pompa resirkulasi mati) dengan menggunakan portable DO meter (Lutron 5512, China)

Parameter kualitas yang diuji adalah total suspended solids (TSS), chemical oxygen demand (COD), Amonia nitrogen $\left(\mathrm{NH}_{3}-\mathrm{N}\right)$, nitrit nitrogen $\left(\mathrm{NO}_{2}-\mathrm{N}\right)$ dan nitrat nitrogen $\left(\mathrm{NO}_{3}-\mathrm{N}\right)$ dan fosfat fosfor $\left(\mathrm{PO}_{4}-\mathrm{P}\right)$. Pengujian TSS dilakukan mengikuti metode pada SNI 6989.3-2019 (BSN, 2019a) dan pengujian COD mengikuti metode pada SNI 6989.732019 (BSN, 2019b), sedangkan pengujian $\mathrm{NH}_{3}-\mathrm{N}, \quad \mathrm{NO}_{2}-\mathrm{N}, \quad \mathrm{NO}_{3}-\mathrm{N}$ dan $\mathrm{PO}_{4}-\mathrm{P}$ menggunakan spektrofotometri dengan reagent mengikuti manual book spektrofotometer (HACH DR2010, USA).

\section{Analisis Data}

\section{Kepatuhan terhadap Baku Mutu}

Target penggunaan efluen IPAL Bulaksumur adalah untuk penyiraman lahan di sekitar asrama, sedangkan jika sedang tidak terdapat kebutuhan air penyiraman, maka efluen IPAL akan dibuang ke selokan. Oleh karena itu, kualitas efluen IPAL akan dibandingkan dengan Baku Mutu Air Limbah menurut Peraturan Menteri Lingkungan Hidup dan Kehutanan No. 68 Tahun 2016 tentang Baku Mutu Limbah Domestik dan Baku Mutu Air Kelas IV menurut Peraturan Pemerintah RI No. 82 Tahun 2001 tentang Pengelolaan Kualitas Air dan Pengendalian Pencemaran Air, dimana air kelas IV adalah air yang peruntukannya untuk pengairan, pertanaman dan penggunaan lain yang mempersyaratkan kualitas yang sama. Baku Mutu air untuk parameter yang dianalisis tersaji pada Tabel 1.

Tabel 1. Baku Mutu Air Limbah dan Baku Mutu Air Kelas IV

\begin{tabular}{ccc}
\hline Parameter & $\begin{array}{c}\text { Konsentrasi* } \\
(\mathbf{m g} / \mathbf{l})\end{array}$ & $\begin{array}{c}\text { Konsentrasi*** } \\
(\mathbf{m g} / \mathbf{l})\end{array}$ \\
\hline $\mathrm{TSS}$ & 30 & 400 \\
$\mathrm{COD}$ & 100 & 100 \\
$\mathrm{NH}_{3}-\mathrm{N}$ & 10 & $0,5^{1)}$ \\
$\mathrm{NO}_{2}-\mathrm{N}$ & - & $0,06^{1)}$ \\
$\mathrm{NO}_{3}-\mathrm{N}$ & - & 20 \\
$\mathrm{PO}_{4}-\mathrm{P}$ & - & 5 \\
\hline
\end{tabular}

*PermenLHK No. 68/2016

**PP No.82/2001

${ }^{1)}$ Tidak dipersyaratkan pada Baku Mutu Air Kelas IV, sehingga menggunakan Baku Mutu Kelas yang lebih tinggi

\section{$\underline{\text { Reliabilitas dan stabilitas }}$}

Reliabilitas suatu IPAL dilihat dari kemampuan IPAL tersebut untuk menghasilkan efluen yang memenuhi baku mutu yang dipersyaratkan. Jika konsentrasi efluen lebih tinggi dari baku mutu maka dianggap IPAL tersebut gagal. Probabilitas kegagalan IPAL dapat dituliskan secara 
matematis seperti dalam Persamaan (1). Reliabilitas (R) (\%) didefinisikan sebagai probabilitas IPAL dapat memenuhi baku mutu dan secara matematis seperti dalam Persamaan (2).

$P_{\text {gagal }}=\frac{n_{\text {gagal }}}{n_{\text {total }}} \times 100$

dengan $P_{\text {gagal }}$ adalah probabilitas kegagalan (\%), $n_{\text {gagal }}$ adalah jumlah data yang tidak memenuhi baku mutu dan $n_{\text {total }}$ adalah jumlah total data yang diambil.

$R=100 \%-P_{\text {gagal }}$

Untuk menelaah lebih lanjut stabilitas kinerja dan reliabilitas dari IPAL, maka dilakukan analisis reliabilitas dengan menggunakan data konsentrasi efluen. Coefficient of reliability (COR) dihitung dengan Persamaan (3) dan semakin kecil nilai COR merepresentasikan nilai reliabilitas yang lebih baik (Bunce \& Graham, 2019; OwusuAnsah et al., 2015).

$$
\begin{aligned}
& \mathrm{COR}=\sqrt{\left(y^{2}+1\right)} \times \exp \left[-Z_{1-a} \sqrt{\left(y^{2}+1\right)}\right] \\
& Z_{1-a}=\frac{\ln X_{s^{-}}\left[\ln m_{x}-0,5\left(y^{2}+1\right)\right]}{\sqrt{\ln \left(y^{2}+1\right)}}
\end{aligned}
$$

Dengan COR adalah coefficient of reliability, $y$ adalah relative standard deviation (RSD), $\mathrm{Z}_{1-\mathrm{a}}$ adalah standardized normal variate (Niku et al., 1979), $m_{x}$ adalah rerata konsentrasi efluen $(\mathrm{mg} / \mathrm{l})$ dan $X_{s}$ adalah baku mutu efluen (mg/l).

\section{Removal efficiency}

Removal efficiency untuk TSS, COD dan $\mathrm{PO}_{4}-\mathrm{P}$ dihitung dengan Persamaan (5).

Removal $=100 \times \frac{\left(C_{i n}-C_{e f f}\right)}{C_{i n}}$

Dengan Removal adalah removal efficiency $(\%), C_{i n}$ dan $\mathrm{C}_{\text {eff }}$ masing-masing adalah konsentrasi influen dan efluen (mg/l).

Efisiensi nitritasi, nitratasi, nitrifikasi dan denitrifikasi
Proses nitrifikasi terjadi dalam dua tahap yaitu nitritasi dan nitratasi. Nitritasi adalah konversi amonia menjadi nitrit oleh bakteri ammonia oxidizing bacteria (AOB), sehingga efisiensi nitritasi dapat didefinisikan sebagai perbandingan antara amonia yang terkonversi dengan konsentrasi awal amonia. Secara matematis, efisiensi nitritasi (\%) dapat dituliskan seperti dalam Persamaan (6).

Nitritasi $=100 \times \frac{\left(T A N_{i n}-T A N_{\text {eff }}\right)}{T A N_{i n}}$

dengan TAN adalah konsentrasi total $\mathrm{NH}_{3}-\mathrm{N}$ (mg/l) dan indeks in dan eff masing-masing menyatakan influen dan efluen.

Nitratasi adalah proses konversi nitrit menjadi nitrat, sehingga efisiensi nitratasi dapat didefinisikan sebagai perbandingan antara konsentrasi nitrit yang terkonversi dengan konsentrasi awal nitrit. Konsentrasi awal nitrit adalah jumlah dari konsentrasi amonia yang terkonversi dan konsentrasi nitrit di influen sedangkan konsentrasi nitrit yang terkonversi menjadi nitrat dapat didefinisikan sebagai selisih antara konsentrasi awal nitrit dengan dengan konsentrasi nitrit di efluen. Secara matematis, efisiensi nitratasi $(\%)$ dapat dituliskan seperti dalam Persamaan (7).

Nitratasi $=100 \times 1-\frac{\text { Nitrit }_{\text {eff }}}{\text { TAN }_{\text {in }}-\text { TAN }_{\text {eff }}+\text { Nitrit }_{\text {in }}}$

dengan Nitrit adalah konsentrasi $\mathrm{NO}_{2}-\mathrm{N}$ $(\mathrm{mg} / \mathrm{l})$ dan indeks in dan eff menyatakan influen dan efluen.

Denitrifikasi dapat didefinisikan sebagai proses konversi dari seluruh bentuk teroksidasi nitrogen (Nox) $\left(\mathrm{NO}_{2}-\mathrm{N}\right.$ dan $\mathrm{NO}_{3}-$ $\mathrm{N}$ ) menjadi $\mathrm{N}_{2}$ (von Sperling et al., 2020), dan secara matematis, efisiensi denitrifikasi (\%) dapat dituliskan seperti dalam Persamaan (8).

Denitrifikasi $=100 \times 1-\frac{N O x_{\text {eff }}}{T A N_{\text {in }}-T A N_{\text {eff }}}$

dengan $\mathrm{NO}_{\text {eff }}$ adalah jumlah konsentrasi $\mathrm{NO}_{2}-$ $\mathrm{N}$ dan $\mathrm{NO}_{3}-\mathrm{N}$ di efluen $(\mathrm{mg} / \mathrm{l})$. 


\section{HASIL DAN PEMBAHASAN}

\section{Karakteristik influen}

Dari hasil wawancara dengan pengelola Bulaksumur Residence, diperoleh informasi bahwa IPAL dibangun pada Januari 2020 dan mulai beroperasi pada Februari 2020 dengan kapasitas rencana $8 \mathrm{~m}^{3} /$ hari. Namun, dikarenakan kondisi pandemi COVID-19 dan dikeluarkannya kebijakan kuliah secara daring, banyak dari penghuni asrama yang kembali ke daerah asal sehingga jumlah aktual pengghuni hanya sedikit. Pada saat pelaksanaan pengamatan kinerja IPAL, kamar di Bulaksumur Residence juga belum terisi penuh. Hal tersebut berdampak kepada debit air limbah pada IPAL menjadi sangat kecil dibandingkan dengan kapasitas rencana yaitu $0,5 \pm 0,4 \mathrm{~m}^{3} /$ hari dengan hydraulic residence time (HRT) sebesar 8,2 \pm 9 hari. Selain itu, beban volumetrik IPAL juga rendah. Konsentrasi influen dan data operasional IPAL tersaji dalam Tabel 2.

\section{Karakteristik efluen dan realibilitas IPAL}

Ringkasan data kualitas efluen IPAL dan profil konsentrasi efluen selama 82 hari pengamatan masing-masing tersaji pada Tabel 3 dan Gambar 2. Konsentrasi efluen untuk setiap parameter sangat bervariasi. Konsentrasi efluen TSS tidak pernah melebihi 14,4 mg/l dan selalu memenuhi kedua Baku Mutu baik Air Limbah maupun Kualitas Air Kelas IV. Hal yang sama terlihat pada konsentrasi COD dan $\mathrm{NH}_{3}-\mathrm{N}$ (dengan masingmasing konsentrasi maksimal 24,0 dan 7,7 $\mathrm{mg} / \mathrm{l})$, kedua parameter tersebut selalu memenuhi kedua Baku Mutu. Hasil yang berbeda tampak pada $\mathrm{PO}_{4}-\mathrm{P}, \mathrm{NO}_{2}-\mathrm{N}$ dan $\mathrm{NO}_{3}-$ N. Selama pengamatan probabilitas ketiga parameter tersebut tidak memenuhi Baku Mutu sebesar 54,2 \% untuk $\mathrm{PO}_{4}-\mathrm{P}, 91,7 \%$ dan 91,7 \% untuk $\mathrm{NO}_{2}-\mathrm{N}$ dan $\mathrm{NO}_{3}-\mathrm{N}$.
Tabel 2. Karakteristik influen dan data operasional IPAL

\begin{tabular}{|c|c|c|c|}
\hline \multirow{2}{*}{ Parameter } & \multicolumn{3}{|c|}{ Nilai } \\
\hline & Min. & Maks. & Rerata \\
\hline \multicolumn{4}{|c|}{ Konsentrasi influen, mg/l } \\
\hline TSS & 6,0 & 49,4 & $15,5 \pm 10,4$ \\
\hline $\mathrm{COD}$ & 21,4 & 136,0 & $66,2 \pm 26,6$ \\
\hline $\mathrm{PO}_{4} \mathrm{P}$ & 6,3 & 17,6 & $9,9 \pm 2,7$ \\
\hline $\mathrm{NH}_{3}-\mathrm{N}$ & 4,1 & 38,0 & $14,6 \pm 8,4$ \\
\hline $\mathrm{NO}_{2}-\mathrm{N}$ & 0,01 & 0,05 & $0,01 \pm 0,01$ \\
\hline $\mathrm{NO}_{3}-\mathrm{N}$ & 1,2 & 2,8 & $2,0 \pm 0,4$ \\
\hline \multicolumn{4}{|c|}{ Konsentrasi DO, mg/l } \\
\hline $\mathrm{R} 1$-aerasi on & 1,1 & 3,8 & $1,9 \pm 0,6$ \\
\hline $\mathrm{R} 1$-aerasi off & 0,0 & 2,1 & $1,4 \pm 0,5$ \\
\hline $\mathrm{R} 2$-aerasi on & 2,0 & 4,3 & $3,0 \pm 0,6$ \\
\hline R2-aerasi off & 0,0 & 3,6 & $2,4 \pm 0,8$ \\
\hline \multicolumn{4}{|c|}{ Parameter lain } \\
\hline Debit, m3 & 0,1 & 1,2 & $0,5 \pm 0,4$ \\
\hline HRT, hari & 1,7 & 32,7 & $8,2 \pm 9$ \\
\hline $\mathrm{C} / \mathrm{N}$ ratio & 1,3 & 11,6 & $4,7 \pm 2,6$ \\
\hline $\begin{array}{l}\text { Beban } \\
\text { volumetrik, } \\
\text { g- } \\
\text { COD/hari/m³ }\end{array}$ & 1,0 & 43,7 & $17,7 \pm 13,8$ \\
\hline
\end{tabular}

Tabel 3. Konsentrasi efluen dan realibilitas IPAL

\begin{tabular}{|c|c|c|c|c|}
\hline & \multicolumn{4}{|c|}{ Konsentrasi, mg/l } \\
\hline & Min. & \multicolumn{2}{|c|}{ Maks. } & Rerata \\
\hline TSS & 0,3 & \multicolumn{2}{|c|}{14,4} & $4,6 \pm 3,4$ \\
\hline $\mathrm{COD}$ & 1,3 & \multicolumn{2}{|c|}{24,0} & $\begin{array}{l}4,0 \pm 5,4 \\
13,9 \pm 6,6\end{array}$ \\
\hline $\mathrm{PO}_{4} \mathrm{P}$ & 3,9 & \multicolumn{2}{|c|}{7,7} & $5,3 \pm 1,1$ \\
\hline $\mathrm{NH}_{3}-\mathrm{N}$ & 0,1 & \multicolumn{2}{|c|}{7,8} & $4 \pm 2,4$ \\
\hline $\mathrm{NO}_{2}-\mathrm{N}$ & 0,04 & \multicolumn{2}{|c|}{0,38} & $22+0.99$ \\
\hline \multirow[t]{3}{*}{$\mathrm{NO}_{3}-\mathrm{N}$} & 1,9 & \multicolumn{2}{|c|}{4,3} & $2,8 \pm 0,5$ \\
\hline & \multicolumn{2}{|c|}{ BM* air limbah } & \multicolumn{2}{|c|}{$\begin{array}{l}\text { BM* air } \\
\text { kelas IV }\end{array}$} \\
\hline & $\mathrm{R}, \%$ & COR & R, \% & COR \\
\hline TSS & 100 & 0,2 & 100 & 0,0 \\
\hline COD & 100 & 0,8 & 100 & 0,1 \\
\hline $\mathrm{PO}_{4} \mathrm{P}$ & $-* *$ & - & 45,8 & 1,1 \\
\hline $\mathrm{NH}_{3}-\mathrm{N}$ & 100 & 0,7 & 8,3 & 4,7 \\
\hline $\mathrm{NO}_{2}-\mathrm{N}$ & $-* *$ & - & 8,3 & 3,6 \\
\hline $\mathrm{NO}_{3}-\mathrm{N}$ & $-* *$ & - & 100 & 0,1 \\
\hline
\end{tabular}

*BM adalah Baku Mutu

**tidak dipersyaratkan

Dari Tabel 3, terlihat bahwa realibilitas IPAL sangat baik (100\%) untuk memenuhi Baku Mutu Air Limbah. Hal tersebut 

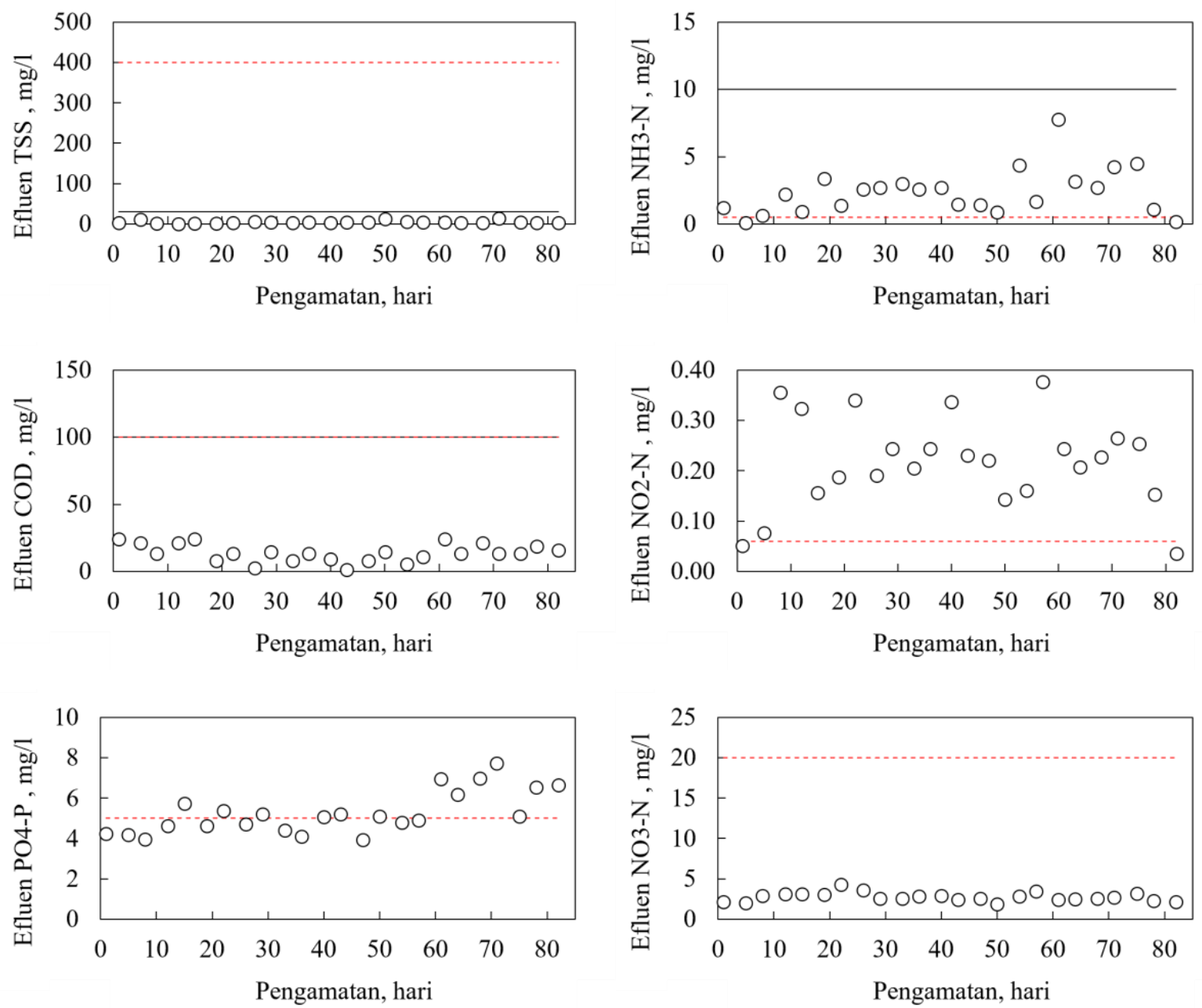

Gambar 2. Profil konsentrasi IPAL. Garis penuh hitam menunjukkan baku mutu air limbah dan garis merah terputus menuniukkan baku mutu air kelas IV

menunjukkan bahwa untuk parameter yang diamati, efluen IPAL aman jika langsung dibuang ke lingkungan. Akan tetapi, jika efluen IPAL akan digunakan sebagai air penyiraman taman, reliabilitas untuk $\mathrm{PO}_{4}-\mathrm{P}$ hanya $45,8 \%$ dan reliabilitas yang lebih buruk terdapat pada $\mathrm{NH}_{3}-\mathrm{N}$ dan $\mathrm{NO}_{2}-\mathrm{N}$ dengan realibilitas sebesar $8,3 \%$. Terlihat hubungan kontradiktif antara nilai reliabilitas dengan COR. Jika pada kedua standar Baku Mutu, semakin besar nilai COR maka reliabilitas akan menurun dan sebaliknya. Menurut Owusu-Ansah et al. (2015) dan Bunce \& Graham (2019), semakin tinggi reliabilitas IPAL, maka semakin kecil COR, hal tersebut juga sejalan dengan hasil penelitian ini. Selain itu teramati pula reliabilitas IPAL $<50 \%$ ditemukan untuk nilai $\mathrm{COR}>1$. Dari Persamaan (3) dan (4), nilai COR dipengaruhi dari konsentrasi rerata efluen $\left(m_{x}\right)$ dan stabilitas konsentrasi efluen, dalam hal ini dinyatakan dalam RSD (y) dimana semakin stabil efluen makan nilai $y$ akan semakin kecil. IPAL yang baik akan menghasilkan nilai konsentrasi efluen rerata yang lebih rendah dari baku mutu $\left(m_{x}<X_{s}\right)$ dan konsentrasi efluen yang stabil (nilai $y$ semakin kecil), sehingga jika diaplikasikan untuk menghitung COR, IPAL yang stabil dan reliabel akan memberikan COR yang rendah. Meskipun terdapat variasi pada konsentrasi efluen dan reliabilitas yang rendah untuk memenuhi standar Baku Mutu Air Kelas IV, kinerja IPAL dalam hal removal efficiency tampak stabil (Tabel 4). Relative standard deviation (RSD) digunakan sebagai indikator kestabilan kinerja. RSD digunakan untuk melihat tingkat presisi suatu data. Semakin kecil RSD, maka 
data tersebut semakin presisi dan nilai RSD < $30 \%$ masih dapat ditolerir sebagai nilai cukup presisi (Eurachem, 2014). Dengan mengelaborasi teori statistik tersebut pada penelitian ini, maka dapat dinyatakan semakin kecil RSD maka proses tersebut semakin stabil. Seluruh nilai RSD pada kinerja IPAL (removal efficency dan nitritasi, nitratasi dan dentrifikasi) lebih kecil dari $30 \%$. Hal ini menunjukkan bahwa kinerja IPAL dapat dikategorikan sebagai cukup stabil. TN removal dan efisiensi denitrifikasi menunjukkan stabilitas yang cukup $(20 \%<$ RSD < 30\%), kemudian TSS, COD dan $\mathrm{PO}_{4}-\mathrm{P}$ removal menunjukkan stabilitas yang baik $(10 \%<\mathrm{RSD}<20 \%)$, terlebih lagi stabilitas yang sangat baik terlihat pada efisiensi nitritasi dan nitratasi (RSD $<10 \%)$. Sebagaimana telah disebutkan sebelumya, realibilitas efluen $\mathrm{NH}_{3}-\mathrm{N}$ dan $\mathrm{NO}_{2}-\mathrm{N}$ sangat rendah untuk memenuhi standar Baku Mutu Air Kelas IV. Besarnya efluen $\mathrm{NH}_{3}-\mathrm{N}$ lebih dipengaruhi oleh proses nitrifikasi (nitritasi dan nitratasi) dimana proses nitritasi lebih dominan dalam menentukan konsentrasi efluen $\mathrm{NH}_{3}-\mathrm{N}$ karena pada tahap ini $\mathrm{NH}_{3}-\mathrm{N}$ dikonversi menjadi $\mathrm{NO}_{2}-\mathrm{N}$. Meskipun efisiensi $\mathrm{NH}_{3}-\mathrm{N}$ maksimal mencapai $99,5 \%$, namun nilai rerata nya hanya sebesar $83,1 \pm 7,9 \%$.

Dari studi terdahulu yang sudah dilakukan (Ardhito, 2019) pada IPAL dengan teknologi MBG dengan intermittent aeration (1 jam aerasi mati dan 3 jam aerasi menyala, konsentrasi DO saat aerasi menyala 5,9 - 6,3 $\mathrm{mg} / \mathrm{l}$ ), dengan COD loading $923 \mathrm{~g} / \mathrm{m}^{3} / \mathrm{hari}$ dengan $\mathrm{C} / \mathrm{N}$ ratio 7,5 , meskipun waktu aerasi yang dilakukan lebih panjang dan konsentrasi DO pada saat aerasi lebih tinggi tetapi diperoleh efisiensi nitritasi $(77,8 \pm 4,4 \%)$ nitratasi $(87,3 \pm 0,1 \%)$ yang lebih rendah dari penelitian ini. Sehingga waktu aerasi yang rendah pada penelitian ini (15 menit) dianggap bukan merupakan faktor yang mempengaruhi efisiensi nitritasi dan nitratasi. Nitrifikasi parsial yang ditandai dengan tingginya efisiensi nitrifikasi (>90\%) dan denitrifikasi $(>75 \%)$ dapat terjadi pada konsentrasi DO yang rendah $(<1,2 \mathrm{mg} / \mathrm{l})$ (Capodaglio et al., 2016), namun hal tersebut tidak terjadi pada IPAL Bulaksumur Residence. Pada penelitian ini, konsentrasi DO saat aerasi berlangsung baik pada tangki aerasi $1 \quad(1,9 \pm 0,6 \mathrm{mg} / \mathrm{l})$ maupun pada tangki aerasi $2(3,0 \pm 0,6 \mathrm{mg} / \mathrm{l})$. Selain itu, rendahnya beban volumetrik IPAL dan $\mathrm{C} / \mathrm{N}$ ratio dapat berkontribusi pada menurunnya COD removal dan efisiensi nitritasi. Pada nilai $\mathrm{C} / \mathrm{N}<10$ efisiensi nitritasi dan nitrasasi akan proporsional dengan $\mathrm{C} / \mathrm{N}$ ratio dan akan berbanding terbalik pada $\mathrm{C} / \mathrm{N}$ ratio $>10$ (Roy et al., 2010).

Tabel 4. Kinerja IPAL

\begin{tabular}{lcc}
\hline \multirow{2}{*}{ Parameter } & \multicolumn{2}{c}{ Nilai } \\
\cline { 2 - 3 } \multicolumn{1}{c}{ Rerata } & RSD \\
\hline COD removal & $68,9 \pm 12,9 \%$ & $18,7 \%$ \\
PO $_{4}$-P removal & $78,4 \pm 9,8 \%$ & $12,5 \%$ \\
Nitritasi & $45,3 \pm 8,6 \%$ & $19,0 \%$ \\
Nitratasi & $83,1 \pm 7,9 \%$ & $9,5 \%$ \\
Denitrifikasi & $97,6 \pm 2,0 \%$ & $2,0 \%$ \\
TN removal & $67,2 \pm 19,3 \%$ & $28,7 \%$ \\
\hline
\end{tabular}

Rendahnya konsentrasi DO dan durasi aerasi diperkirakan menjadi penyebab rendahnya COD removal pada penelitian ini $(78,4 \pm 9,8 \%)$. Dari laporan kinerja IPAL domestik yang terpasang di toilet umum dengan aerasi menggunakan blower (Setyapeni et al., 2021), meskipun aerasi dilakukan secara menerus selama 24 jam, tetapi konsentrasi DO rerata yang hanya mencapai kisaran $0,4 \quad-0,5 \mathrm{mg} / \mathrm{l}$ hanya menghasilkan COD remvoval sebesar 54,5 73,3\%. Didapatkan iformasi dari dari pengelola IPAL bahwa sejak pertama kali dioperasikan, belum pernah dilaksanakan perawatan pembersihan $\mathrm{MBG}$, hal tersebut diduga dapat memberikan kontribusi terhadap menurunnya efisiensi transfer oksigen yang ditandai dengan rendahnya konsentrasi DO di tangki aerasi.

Pada umumnya, semakin tinggi efisiensi nitratasi maka akumulasi $\mathrm{NO}_{2}-\mathrm{N}$ semakin rendah karena $\mathrm{NO}_{2}-\mathrm{N}$ terkonversi menjadi 
$\mathrm{NO}_{3}-\mathrm{N}$. Namun pada pengamatan terlihat hal yang sebaliknya. Walaupun efisiensi nitratasi tinggi dan stabil $(97,6 \pm 2,0 \%$, RSD $2,0 \%)$, reliabilitas efluen $\mathrm{NO}_{2}-\mathrm{N}$ untuk memenuhi standar Baku Mutu Air Kelas IV masih sangat rendah $(8,3 \%)$. Perlu penelitian lebih lanjut untuk mengetahui secara pasti penyebab hal tersebut.

Pada penelitian ini, total nitrogen (TN) didefinisikan sebagai jumlah $\mathrm{NH}_{3}-\mathrm{N}, \mathrm{NO}_{2}-\mathrm{N}$ dan $\mathrm{NO}_{3}-\mathrm{N}$. Dari Tabel 4 tampak TN removal efficiency lebih dipengaruhi oleh proses denitrifikasi. Konsentrasi DO berpengaruh pada proses denitrifikasi dimana proses denitrifikasi terjadi pada kondisi anoksik atau anaerobik. Efisiensi denitrifikasi sebesar $64,8 \%$ dan $77,0 \%$ tercapai pada konsentrasi DO masing-masing sebesar 0,45 dan 0,28 mg/l (Viotti et al., 2016). Pada IPAL Bulaksumur Residence teramati bahwa efisiensi denitrifikasi sebesar 67,2 $\pm 19,3 \%$ (pada konsentrasi DO saat tanpa aerasi sebesar $1,4 \pm 0,5$ dan $2,4 \pm 0,8 \mathrm{mg} / \mathrm{l}$ pada tangki aerasi 1 dan 2) dapat tercapai dan $100 \%$ reliabilitas efluen $\mathrm{NO}_{3}-\mathrm{N}$ untuk memenuhi standar Baku Mutu Air Kelas IV. Hal tersebut merupakan capaian yang baik karena proses nitrifikasi dan denitrifikasi dapat berlangsung pada satu reaktor yang sama dan membuktikan keberhasilan strategi aerasi secara intermittent.

\section{KESIMPULAN}

IPAL Bulaksumur Residence dibangun secara khusus memanfaatkan MBG untuk proses aerasi dengan memanfaatkan resirkulasi efluen dan mengaplikasikan strategi aerasi secara intermittent. Pada saat dilakukan evaluasi, IPAL sudah beroperasi selama kurang lebih 200 hari tanpa dilakukan evaluasi dan perawatan atau pembersihan sampai dengan evaluasi dilakukan selama 82 hari pengamatan. Meskipun demikian, dapat tercapai performa yang baik ditandai dengan removal TSS, COD, $\mathrm{PO}_{4}-\mathrm{P}$ dan TN (masingmasing sebesar $68,9 \pm 12,9 \%, 78,4 \pm 9,8 \%$, $45,3 \pm 8,6 \%$ dan $63,4 \pm 13,7 \%$ ) serta reliabilitas yang tinggi (100\%) untuk memenuhi standar Baku Mutu Air Limbah Domestik yang dipersyaratkan pada PermenLHK No. 68 tahun 2016. Jika efluen IPAL akan digunakan sebagai air penyiraman taman (untuk memenuhi kriteria Baku Mutu Air Kelas IV PP No.82 tahun 2001), maka diperlukan perhatian khusus untuk memperbaiki kinerja nutrient removal karena reliabilitas untuk efluen $\mathrm{PO}_{4}-\mathrm{P}, \mathrm{NH}_{3}-\mathrm{N}$ dan $\mathrm{NO}_{2}-\mathrm{N}$ yang masih rendah (masing-masing sebesar 45,8\%, 8,3\% dan $8,3 \%$ ). Perawatan secara rutin perlu dilakukan terutama pada pembersihan MBG secara berkala untuk mendapatkan efisiensi transfer oksigen selalu terjaga pada kondisi terbaik sesuai dengan desainnya.

Secara umum, kombinasi antara aerasi menggunakan MBG dan strategi aerasi secara intermittent (15 menit aerasi menyala dan 15 menitaerasi mati) berhasil menunjukkan removal efficiency TSS, COD, $\mathrm{PO}_{4}-\mathrm{P}$ dan TN yang baik serta efisiensi nitritasi, nitritasi dan denitrifikasi yang baik pula. Hasil penelitian ini diharapkan mampu memberikan informasi penting yang dapat dipergunakan sebagai dasar penyempurnaan proses aerasi menggunakan MBG dan optimasi strategi aerasi untuk menghasilkan kinerja dan reliabilitas yang lebih baik.

\section{UCAPAN TERIMA KASIH}

Penulis menyampaikan terima kasih kepada Direktorat Perencanaan Universitas Gadjah Mada dan Departemen Teknik Sipil dan Lingkungan Fakultas Teknik Universitas Gadjah Mada atas dukungan dana untuk pelaksanaan seluruh kegiatan penelitian ini.

\section{REFERENSI}

Ahmad, J. S. M., Cai, W., Zhao, Z., Zhang, Z., Shimizu, K., Lei, Z., \& Lee, D.-J. 2017. Stability of algal-bacterial granules in continuous-flow reactors to treat varying strength domestic wastewater. Bioresource Technology. 244(June): 225-233. 
https://doi.org/10.1016/j.biortech.2017.07 .134

Ahmad, J. S. M., Zhao, Z., Zhang, Z., Shimizu, K., Utsumi, M., Lei, Z., Lee, D.-J., \& Tay, J. H. 2019. Algal-bacterial aerobic granule based continuous-flow reactor with effluent recirculation instead of air bubbling: Stability and energy consumption analysis. Bioresource Technology Reports. 7, 100215. https://doi.org/10.1016/j.biteb.2019.1002 15

Ardhito, M. M. 2019. Perancangan Dan Evaluasi Start-Up Instalasi Pengolahan Air Limbah (Ipal) Kamar Mandi Umum Wisdom Park Ugm Dengan on-Off Aeration Tank Untuk Menurunkan Kadar Nitrogen.

http://etd.repository.ugm.ac.id/home/deta il_pencarian/172414

Badan Standardisasi Nasional (BSN), 2019. SNI 6989.3:2019. Air dan air limbah Bagian 3: Cara uji padatan tersuspensi total (Total Suspended Solid/TSS) secara gravimetri.

Badan Standardisasi Nasional (BSN), 2019. SNI 6989.73:2019. Air dan air limbah Bagian 73: Cara uji kebutuhan oksigen kimiawi (Chemical Oxygen Demand/COD) dengan refluks tertutup secara titimetri.

Bunce, J. T., \& Graham, D. W. 2019. A Simple Approach to Predicting the Reliability of Small Wastewater Treatment Plants. Water. 11(2397): 1-14. https://doi.org/10.2166/wst.1990.0174

Capodaglio, A. G., Hlavinek, P., \& Raboni, M. 2016. Advances in wastewater nitrogen removal by biological processes: state of the art review. Revista Ambiente e Agua, 11(2): 250-267. https://doi.org/10.4136/1980-993X

Eurachem. 2014. The Fitness for Purpose of Analytical Methods. In Eurachem Guide, ISBN: 0-94948926-12-0. http://www.eurachem.org/images/stories/ Guides/pdf/valid.pdf
Mahlil, T., Inoue, T., Matsumoto, Y., Aoki, S., Shigeru, K., Yokota, K., Rasul, E., \& Makoto, S. 2018. Effect of nutrient inputs on water quality change and phytoplankton growth in Atsumi Bay. Journal of Engineering and Technological Sciences. 50(4): 548-565.

Matthews, J. A. 2008. Nutrients: Phosphorus, nitrogen source, impact on water quality. Water Quality/Impaired Waters. 3(22). https://doi.org/10.4135/9781446247501.n 2679

Niemi, A., Edlmann, K., Carrera, J., Juhlin, C., Tatomir, A., Ghergut, I., Sauter, M., Bensabat, J., Fagerlund, F., Cornet, F. H., Vilarrasa, V., \& McDermott, C. I. 2006. Waste characterization. In Industrial Waste Treatment Handbook (2nd ed., pp. 83-126). https://doi.org/10.1007/978-94024-0996-3_7.

Niku, S., Schroeder, E. D., Samaniego, F. J., D, E., \& Samaniego, J. 1979. Performance sludge processes of activated and design reliability-based. Water. 51(12): 2841-2857.

Owusu-Ansah, E. D. G. J., Sampson, A., Amponsah, S. K., Abaidoo, R. C., \& Hald, T. 2015. Performance, compliance and reliability of Waste stabilization pond: Effluent discharge quality and environmental protection agency standards in Ghana. Research Journal of Applied Sciences, Engineering and Technology. 10(11): 1293-1302. https://doi.org/10.19026/rjaset.10.1825

Putro, S. S. 2017. the Study of Water Quantity and Quality (Case Study: Gajahwong Watershed). Journal of the Civil Engineering Forum. 2(3): 261. https://doi.org/10.22146/jcef.26588

Rompas, T. M., Rotinsulu, W. C., \& Polii, J. V. B. 2019. Analisis Kandungan E-Coli Dan Total Coliform Kualitas Air Baku Dan Air Bersih Pam Manado Dalam Menunjang Kota Manado Yang Berwawasan Lingkungan. Cocos. 1(5).

Roy, D., Hassan, K., \& Boopathy, R. 2010. 
Effect of carbon to nitrogen $(\mathrm{C}: \mathrm{N})$ ratio on nitrogen removal from shrimp production waste water using sequencing batch reactor. Journal of Industrial Microbiology and Biotechnology. 37(10): 1105-1110.

https://doi.org/10.1007/s10295-0100869-4

Saraswati, S. P., Ardion, M. V., Widodo, Y. H., \& Hadisusanto, S. 2019. Water Quality Index Performance for River Pollution Control Based on Better Ecological Point of View (A Case Study in Code, Winongo, Gadjah Wong Streams). Journal of the Civil Engineering Forum. 5(1): 47. https://doi.org/10.22146/jcef.41165

Setyapeni, O. Y., Saraswati, S. P., \& Ahmad, J. S. M. 2021. Perancangan dan evaluasi kinerja sistem lumpur aktif di IPAL toilet Wisdom Park UGM dalam mengurangi kadar COD dan nitrogen. Prosiding Simposium Nasional Teknologi Ingrastruktur Abad Ke-21. 586-591. https://s.id/ProsidingSNTI
Shalindry, R. O., Rochmadi, \& Budhijanto, W. 2015. Penguraian Limbah Organik Secara Aerobik Dengan Aerasi Menggunakan Microbubble Generator Dalam Kolam Dengan Imobilisasi Bakteri. Jurnal Rekayasa Proses. 9(2): 58-64. https://doi.org/10.22146/jrekpros.31035

Viotti, P., Collivignarelli, M. C., Martorelli, E., \& Raboni, M. 2016. Oxygen control and improved denitrification efficiency by dosing ferrous ions in the anoxic reactor. Desalination and Water Treatment. 57(39): 18240-18247. https://doi.org/10.1080/19443994.2015.1 089200

von Sperling, M., Verbyla, M. E., \& Oliveira, S. M. A. C. 2020. Assessment of Treatment Plant Performance and Water Quality Data: A Guide for Students, Researchers and Practitioners, First ed. IWA

Publishing. https://doi.org/10.2166/9781780409320. 